Kong. Res. J. 4(1): 5-7, 2017

ISSN 2349-2694

Kongunadu Arts and Science College, Coimbatore.

\title{
EQUILIBRIUM OF ECOLOGY AND ENGLISH CHALLENGES FOR TOMORROW'S LEADERS: A STUDY
}

\author{
Chinnadurai, $T^{*}$. and P. Nagaraj \\ Department of English, Bharathiar University, Coimbatore \\ *E.mail: duraiheartfriend@gmail.com
}

\begin{abstract}
The vision of the greenish world refashions lightning into brownish ground. When our human minds enlarge, our souls and hearts become brownie and narrow. Our world is expected to face massive calamities which have already given enough signs to be aware of disasters like Tsunami, earthquakes, global warming and less prime span of living. According to the poet W.H. Auden "a culture is no better than its woods". Today's children are being taught how to cut away the trees and build fine air conditioner rooms. Being an English teacher, one has the greatest responsibility in language classroom in molding the future leaders. If we do not care of our square classroom today, our circle globe will be no more for next generation. Only our four pillars of classroom are to shape our Earth. Students are facing many problems in indoor learning like attention difficulties, diminished use of sense, hyperactivity, and childhood obesity and disconnection from real things. English teacher has to have the efficiency to transfer students' ability into positive environmental action to preserve our earth as over grown living areas. It's our responsibility to grow our children with greenish perspective. This paper focuses how to develop our ecological system through English for tomorrow's leaders.
\end{abstract}

Keywords: greenish world, massive calamities, span of living, molding the future leaders, outdoor learning, positive environmental, balancing ecological system

Ecocriticism or ecological studies are known as "green cultural studies", "ecopoetics", and "environmental literary criticism". Cheryll Glotfelty describes it as the study of the relationship between literature and the physical environment. It is the human perception of nature and its consuming natural core by human beings (Glotfelty Cherill and Harold Fromm, 1996).

Einstein said, "Remove the bee from the Earth and at the same stroke you remove at least one hundred thousand plants that will not survive". If the bees disappeared off the face of the Earth, man would only have four years left to live. No more bees, no more pollination, no more plants, no more animals, and no more man (Calaprice and Alice, 1998).

Balancing our ecological system is the essential duty to all human beings. In the name of modernism, sixth sense (common sense which only human deserves it) eradicates other living organisms which are underneath of human. Still humans do not have the knowledge that surviving without these living natures are impossible in this world. Though government rules and laws and NGOs are more in number and have been doing their services and creating awareness among society about ecological imbalance and problems which faced by humans are lamented. There may no special initiative taken by academicians and corporation bodies to preserve ecology.

Ralph Waldo Emerson, "He who knows what sweets and virtues are in the ground, the waters, the plants, the heavens, and how to come at these enchantments, is the rich and royal man" (Emerson and Ralph Waldo, 1860).

God has created this world as like one has to kill others to make him/her/it alive or survive. Although we call ancient as uncivilized, he is well known about art of balancing ecological system which civilized man (modern human being) fails to understand. For the benefit of civilization, nature has been corrupted and turned into desert. Civilized men are uncivilized in ecological unbalancing.

In historical perceptive, it is said in both Indian and western epics like Mahabharata and the Bible. In Mahabharata stated that "The forest protects the tiger and the tiger protects the forest" as well as in Tolkappiyam, the division by names of lands is like Kurinji, Mullai, Marutham, Neital and Paalai (Tolkappiyam by Tolkappiyar). This indicates ancient people's cultivation and its importance in the preservation of nature and ecological system. The ecological studies are more importantly, for the ethical stand it takes, its commitment to the natural world as an important entity in itself rather than 
simply as an object of thematic study. It focuses on natural writing, romantic poetry and canonical literature to take in film, TV, theatre, animal stories, architectures, scientific narratives and an extra ordinary range of texts, literary and non-literary.

Today ecological studies are focusing on damaging and altering hub of the natural ecosystem by human beings. Nature is destroyed by man by various factors like smugglers and poachers, human greed, atmospheric pollution, threats of global warming, population pressure and nuclear weapons. Though these disasters are very well known to all, our carelessness is still being remained. It is the duty of the educated ones to make environmental awareness as well as the importance of maintaining the ecological system among the unknown ones. As a teacher, especially English language teacher, one should be aware of these calamities and orient students on the imbalance of nature and ecosystem. English language teacher has the role of teaching not only English language but also ecological misbalancing as language is a part of the eco system.

In this modern world, there are many literary works with ecological themes like William Blake's The Tyger, Robert Frost's Stopping by woods, Raja Rao's Kanthapura, R.K. Narayan's Malgudi Days etc and the ideal example is Ruskin Bond books especially Room on the Roof (Krishnaswamy and Ram, 2015). Using these literary texts, English teacher can craft students with English as well as ecological studies.

Blake.

Lines from the poem "The Tyger" by William

Tyger Tyger, burning bright,

In the forests of the night;

What immortal hand or eye,

Could frame thy fearful symmetry?

(Blake, William)

This is the poem about Tiger which tells Tiger's braveness and its good qualities. Mostly an English teacher narrates this poem from the author's or his own point of view or ready-made notes but many teachers fail to implement this theme into real or day to day life. Even in the higher education, only theoretical perspective on ecological issues being dealt in the classrooms but practical orientation to students on ecological issues is the need of thehours.

English language teacher should not bring the meaning of the poem alone, but he/she should have multi-talents to share additional information about the theme of the poem which is correlated to the real life to enrich the students' mentality in different perceptive, especially at ecological symmetry. In this poem "The Tyger", author describes Tiger's qualities of physical appearance of immortal eye and hand, cosmos like fiery eyes, twist sinews of the tiger's heart. Creator should have very conscious of creating horrible heart and compare him to a blacksmith who enjoys seeing of his eternal creation of beauty. The awe of the tiger as well as sheer physical aesthetic is combined beauty and horror of the tiger. In addition to that teacher can notify on the subject of tiger's scarcity and its roles in India and other countries. So many interesting facts can be included in the language class room just like the tiger can hunt during night time alone, how to preserve and destroy tigers, there are only 3890 tigers remain in this world, facts on the reproduction of tiger and human related news like Tiger as prey, man-eating tigers, commercial hunting and traditional medicine, and captivity can be discussed.

The next step of teaching is ecological vocabularies and grammatical sentences in language learning classroom. Teacher can pick the vocabularies and sentences which are related to the ecological studies and teach the meaning of the words and sentences with the help of flashcard, dictionary, green board, and projector. Students can feel and live with the nature without harming it. For example, some of the natural and sentence words in this poem which are related with nature like immortal hand or eye, fearful symmetry, distant deeps or skies, Burnt, sinews of thy heart, wings, seize the fire, heart began to beat, watered heaven, deadly terrors clasp and hammer can be taught to students. Some other activities can be conducted for students to the taking them zoo or forest visit or museum to demonstrate and experience the real life examples of nature. Present and future world is more in need of natural existence than aesthetic.

This method of teaching has more advantages but only few disadvantages. Students can understand the importance of nature, how to live with nature without harming or disturbing. It helps them to view innovative and broader perceptive of learning which facilitate to solve their day to day problems in real life and also future generation will obtain greenish environment to survive in our Earth. Sometimes, teaching ecological studies in language learning classroom pushes literature and aesthetic sense out of the text and student's imagination can be beyond the language learning. Learners can acquire more additional information than core of the text. So teacher should aware of his/her teaching to learners with effective learning of English as well as ecological imbalance. 
At culminating, human beings should understand the relation with nature of living is the best part of their present and future life. In this world, each and every living and non-living being is interrelated with one another. There is a relationship with cosmic space and butterfly which functioning nook and corner of the entire organism in this world. Anyone can give awareness of preserving our natural Earth. A language teacher's support should be more and effective among future leaders of this world.

\section{REFERENCES}

Glotfelty, Cherill and Harold, Fromm, 1996. The Ecocriticism Reader. Athens, Ga.: University of George Press.
Calaprice and Alice, 1998. The Ultimate Quotable Einstein. Edited, Princeton University Press, Princeton, New Jersey.

Emerson and Ralph Waldo. 1860. The Conduct of Life. Boston: Ticknor and Fields, reprinted by Forgotten Books.

Tolkappiyam by Tolkappiyar, between third century BCE and the third century CE.

Krishnaswamy N. and Ram R.V. 2015. Working with Contemporary Literary Theory. Bloomsbury Publication.

Blake, William. The Tyger, The Oxford Book of English Verse. 